\title{
17 Picturing Medicine in Daily life: Court and Commoner Perspectives in Song Era Paintings
}

\author{
TJ Hinrichs*
}

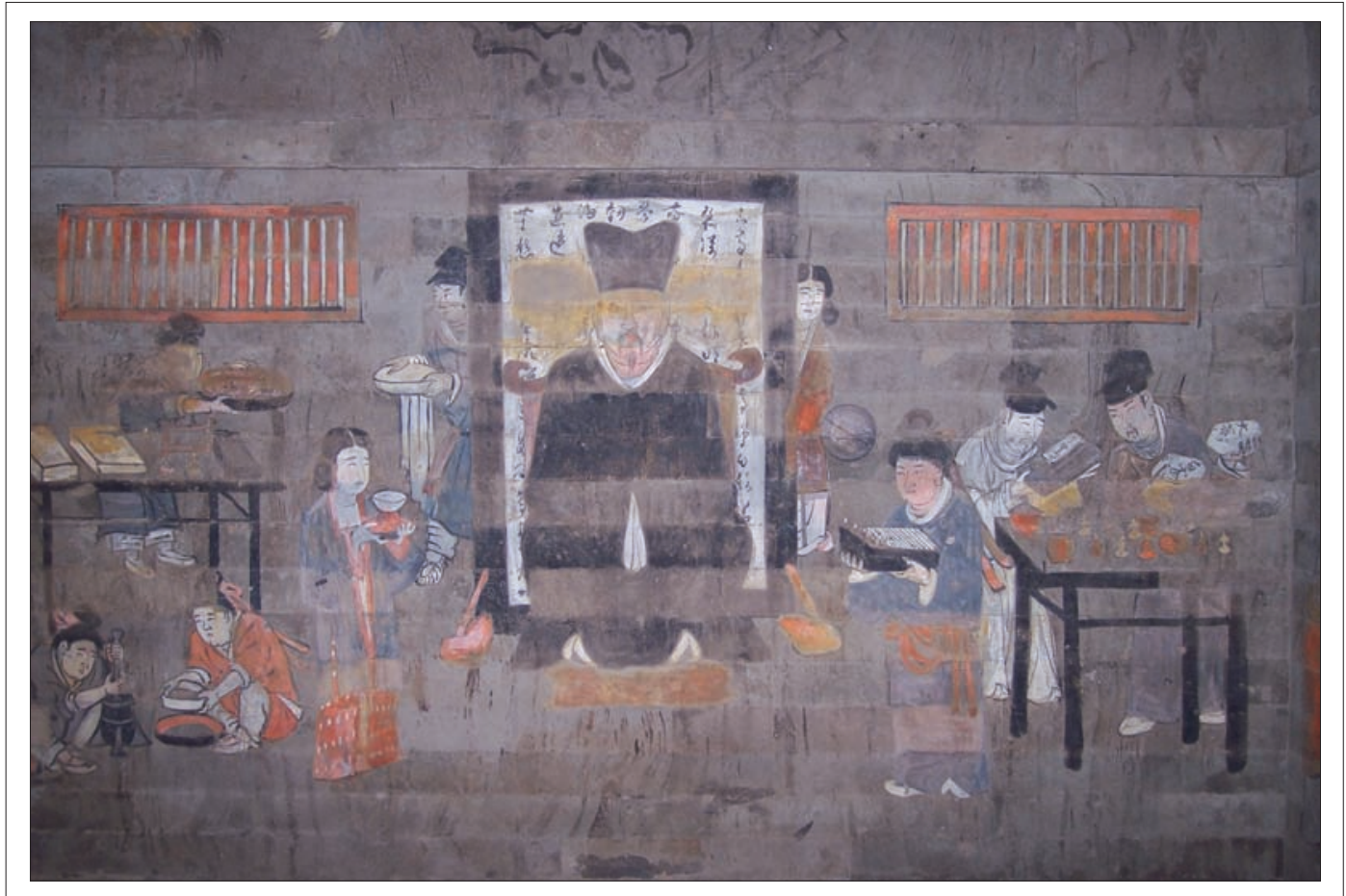

Figure 17.1 Hancheng tomb, north wall mural. $\odot$ TJ Hinrichs

Three paintings of medical activity survive from the Song period: ${ }^{1}$

1) a mural depicting a medicinal production workshop from a c. 1070 tomb, recently discovered in Hancheng 韓 城, Shaanxi (Fig. 1);

2) the scroll Qingming shanghe tu 清明上河圖 ('Qingming on the River'), which includes two pharmacies,

* For this chapter, I owe debts of gratitude to Chen Hao 陳吴, for arranging for me to visit the Hancheng tomb; to Li Jugang 李舉 鋼 of the Shaanxi Archaeological Institute for accompanying us to the tomb installation and answering my questions; to An-yi Pan for guidance on Song art history, especially on the Qingming scroll; to Jeehee Hong for introducing me to middle-period art and archaeology, for collaborating with me on an earlier paper on the Hancheng tomb as a whole (see Hong and Hinrichs 2015); to Maria Fernandes, Durba Ghosh, Rachel Prentice, Sara Pritchard, and Marina Welker for detailed comments on an earlier version of the paper; and to an anonymous reviewer. We know the existence of one other painting listed as Village Doctor (Cunyi 村醫), no longer extant, by Chen Tan 陳坦 (Northern Song). See Deng Qiaobin 2005, p. 125. most likely produced at Huizong's 徽宗 court (r. 1101-25), and attributed to Zhang Zeduan 張擇端 (1085-1145) (Fig. 2);

3) another court painting,Jiuaitu炎艾圖 (Moxibustion), showing an itinerant doctor treating a patient in a rural setting, probably produced under Gaozong 高宗 (r. 1127-63), and attributed to Li Tang 李唐 (c.1050-1130) (Fig. 3).

The patrons of each painting - respectively a provincial pharmaceuticals merchant and his family, Huizong's Northern Song court, and Gaozong's Southern Song court - specifically commissioned objects that would visually celebrate the accomplishments of the sponsors. In each case, those achievements entailed the activation of positive social relations and joint communal activities productive of medical healing. This paper explores and compares the ways in which each painting idealises medical practice in social context, and in so doing affirms the efficacy and authority of the Hancheng merchant and of the two Song emperors.

Before examining each painting in turn, it is worth surveying what the three paintings share beyond the theme of medicine - what makes their comparison (as opposed to mere juxtaposition) useful to their analysis. 


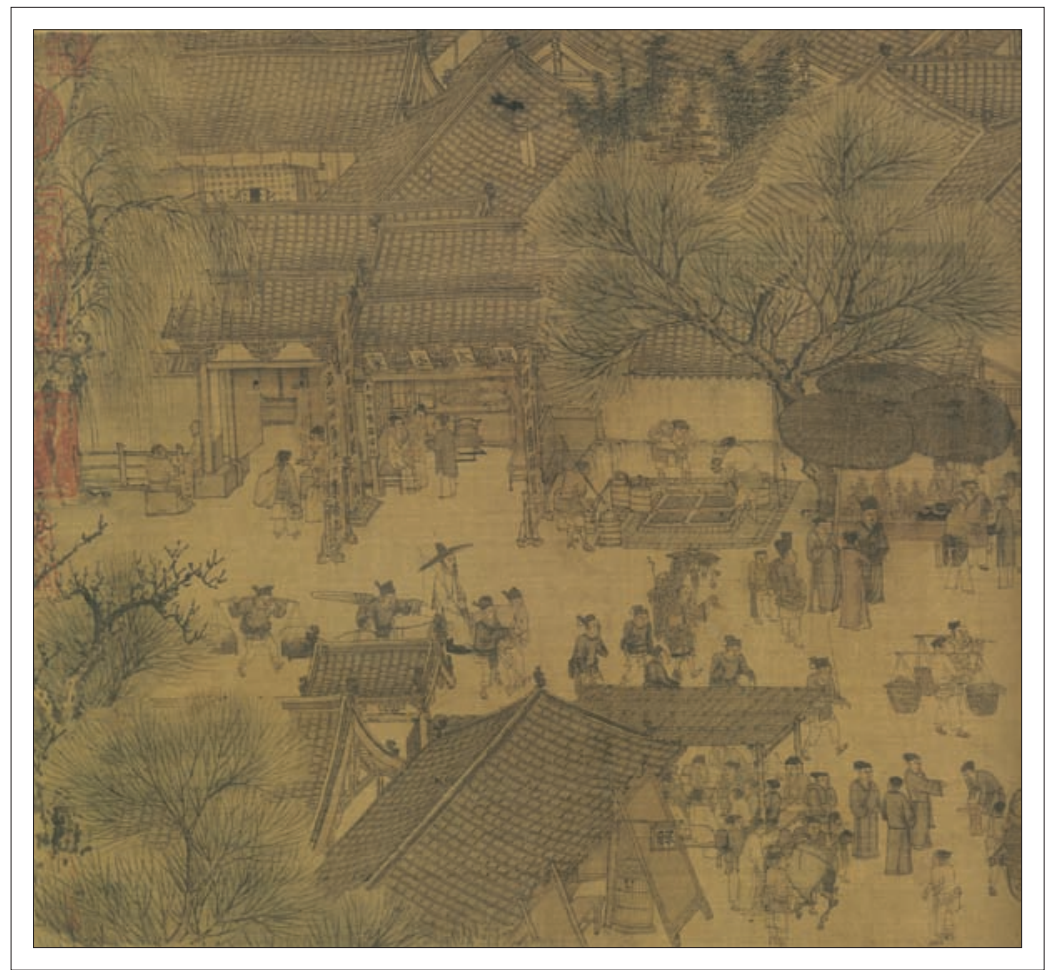

Figure 17.2 Street Scene with Pharmacy from Qingming on the River, attributed to Zhang Zeduan (1085-1145). $\odot$ Courtesy of Palace Museum, Beijing

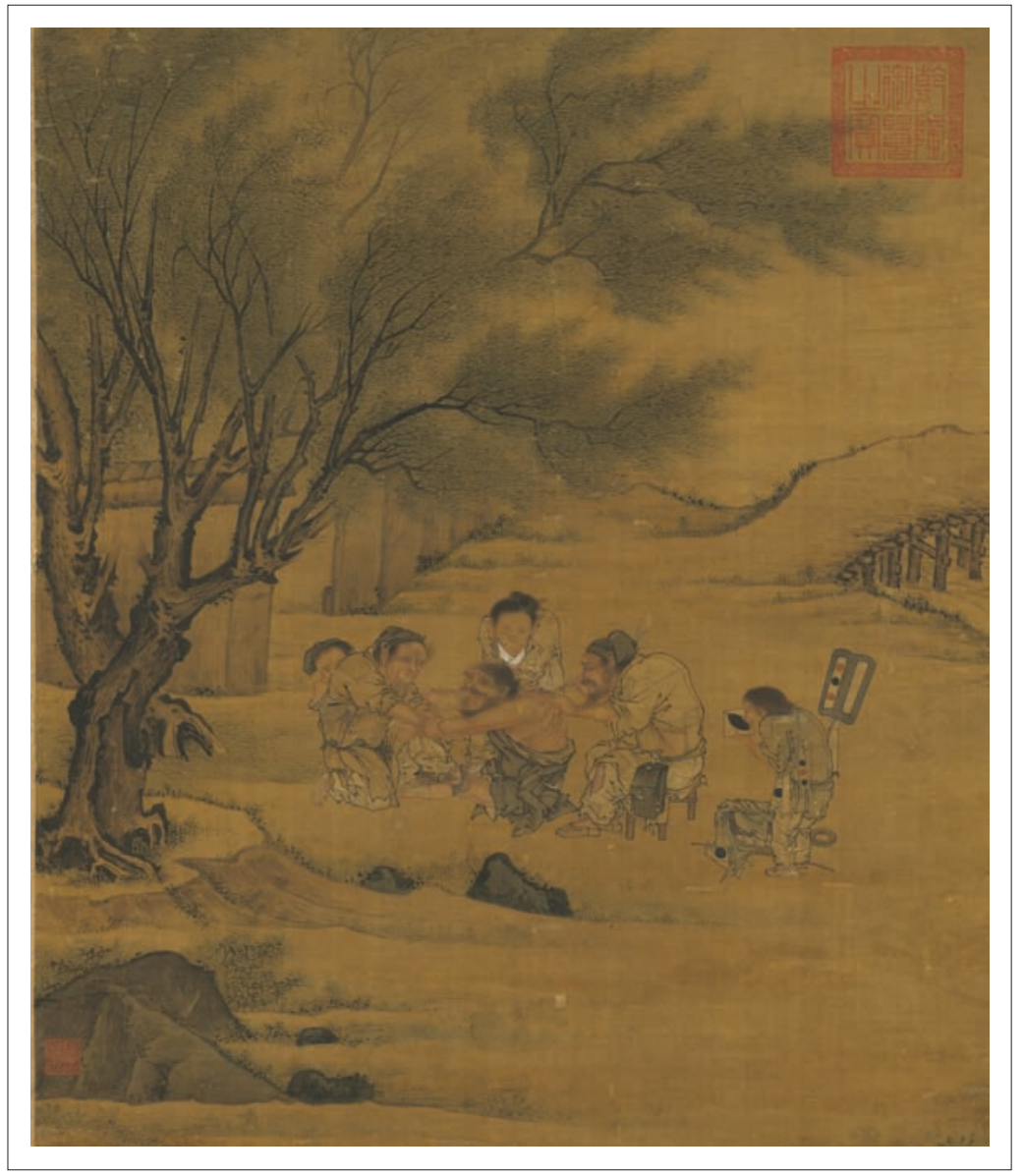

Figure 17.3 Moxibustion, attributed to Li Tang (c.1050-after 1130). ${ }^{\odot}$ Courtesy of The Collection of the National Palace Museum, Taipei 

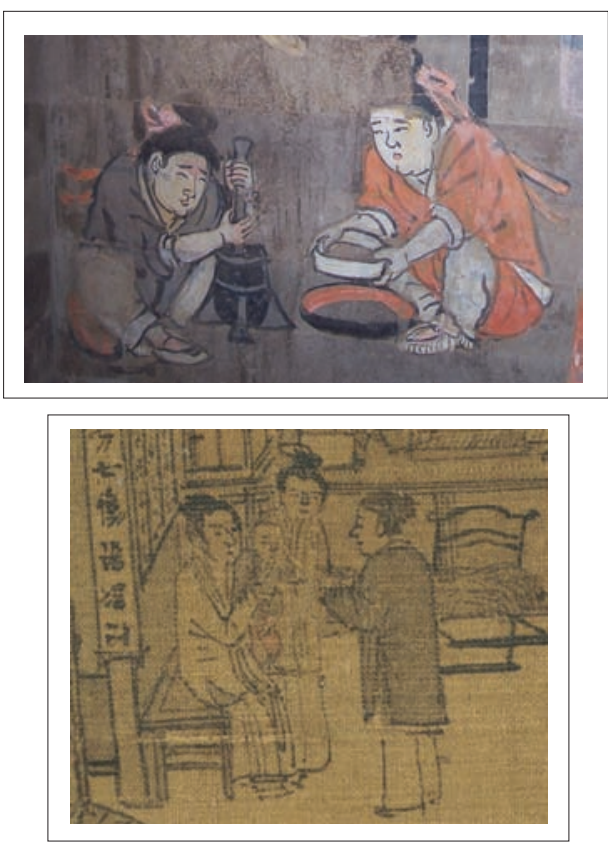

First, each painting framed the patron's accomplishments in relation to social ideals of medical production and practice, distilled those achievements into vignettes, then translated key moments of those episodes into a visual mode, and did so in accord with the contemporary styles, respectively, of tomb mural and court 'commoner customs' paintings. While the disparate contexts of merchant burials and courtly displays seem unlikely to share common conventions, in all three the painters portray complex social situations that generate interpersonal vitality. Where, in a landscape painting, our eye might trace flows of Qi through clouds, rocks, and trees, in these paintings we can follow interactions amongst pairs and groups of people: the paintings signal interpersonal engagement not only through involvement in common activities, but through such techniques as portraying affect (most dramatic and vivid in Moxibustion), and eye contact between participants (Fig. 4).

Second, all three paintings are sites for the interpenetration of official and non-official medical activities. In the first painting, we find the state contributing to commercial enterprise with one of its medical publications: the tomb mural prominently features a medical book commissioned by Emperor Taizong 太宗 (r. 976-97), Taiping shenghuifang 太平聖惠方 (the Taiping ['Great Peace' Era] Formulas of Sagely Grace, $992 \mathrm{CE}$ ) (see Fig. 1). The two court paintings, like others of 'commoner customs', pay particular tribute to the court's ability to establish and inculcate good customs and mores amongst the populace - here healing practices productive not only of therapeutic but of social and moral efficacy.
Figure 17.4 Eye contact: a. (top left) detail of Fig. 1. $\odot$ TJ Hinrichs;

b. (below) detail of Fig. 2. $\odot$ Courtesy of Palace Museum, Beijing; c. (bottom right) detail of Fig. $3 . \odot$ Courtesy of National Palace Museum, Taipei

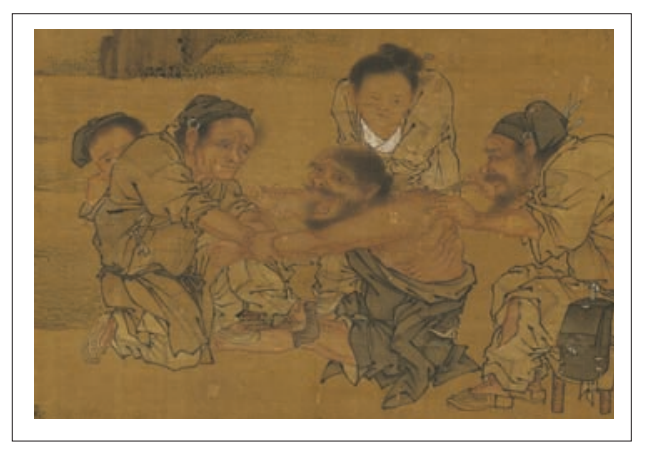

These intersections of state, society, and medicine are not surprising if we consider the era that produced them. Over the long arc of imperial Chinese medical history, the Song (96o-1279 CE) is distinguished by great government projects of medical book production and distribution, including the Taiping Era Formulas; by major augmentations of the medical bureaucracy, of which we see indications in the Qingming scroll; and by innovative campaigns to reform southern healing customs, to bring them into line with norms similar to those portrayed in Moxibustion. ${ }^{2}$ Examining each painting in turn gives us small windows that open onto differently-positioned and shifting ideals of medical, social, and imperial efficacy and authority (Fig. 5).

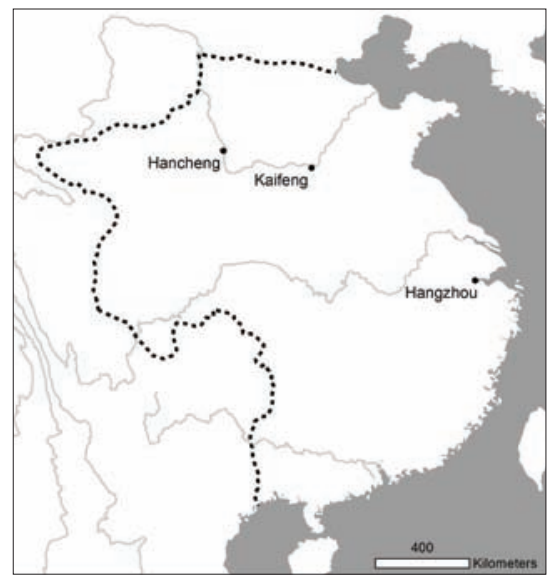

Figure 17.5 Map of painting production sites in the Song era c. 1070-1100 CE. Map created by Michael Castos

2 For an overview of Song medical policies, with illustrations that include the three paintings discussed in this chapter, see Hinrichs and Barnes 2013, pp. 113-29. 


\section{A Commoner Image of Pharmaceutical Production}

Besides activist state policies, the Song era is notable for a dramatic expansion of commerce, and consequently for the growth of a class of affluent non-literati merchants and landholders. ${ }^{3}$ The additional relaxation of earlier restrictions on commoner burials and death rites led to the emergence of lavishly decorated commoner tombs such as the one found at Hancheng. The Hancheng tomb's centrepiece, the mural on its north wall, also attests to one of the avenues to commoner wealth, pharmaceutical trade, and the contribution of a government publication, the Taiping Era Formulas, to that enterprise. However the occupant came by the book, it was obviously a prized possession, and it was an expensive one: if the occupant possessed the book in its entire 100-chapter edition, it might have cost about as much as the state paid its mid-level military men in three years. ${ }^{4}$

In most ways, the tomb is typical of other north China burials of the time. It was discovered in March 2009 in the course of a Hancheng Municipal Mining Bureau project, and was excavated, encased in concrete, and removed by the Shaanxi Province Archaeological Research Institute. ${ }^{5}$ The tomb is south-facing, $2.45 \mathrm{~m}$ long, $1.8 \mathrm{~m}$ wide, and $2.25 \mathrm{~m}$ tall, the tomb opening just large enough for entry by a single person. Inside the chamber, archaeologists found the skeletons of a $1.8 \mathrm{~m}$-tall man and a $1.65 \mathrm{~m}$-tall woman, heads oriented to the north, laid out side by side on a brick platform topped by a wooden couch carved with peony designs. The woman occupant held coins in her

For a discussion of those historical shifts and their effects on medicine, see Hinrichs and Barnes 2013, pp. 115-18. For an overview of the economic transition, see Shiba Yoshinobu 1970. On commercial markets, a typical book ran 5 o cash/juan. If this edition of the Taiping Era Formulas was typical, it probably sold for around 5,00o cash. For book prices and cost of living figures, see Cheng Minsheng 2008, pp. 372-3, 567, 570.

Nothing in the tomb tells us how the occupant acquired the book; whether he possessed the entire 100 chapters or just a portion, whether he had purchased it outright on the market, whether it had been gifted to him, whether he had stolen it, or whether he had personally copied it, as Taizong intended, at the local prefectural office. An anonymous reader suggested that the occupant may have been a functionary in the medical bureaucracy. Again, nothing in the mural suggests that he currently was or formerly had been a medical official, but some medical officials are known to have set up commercial pharmacy shops both in the capital and in their own hometowns. For examples, see discussion of Qingming Scroll below.

5 Hancheng borders the west side of the Yellow River in the northeast of the Guanzhong plain, roughly 24okm north-east of Xi'an.

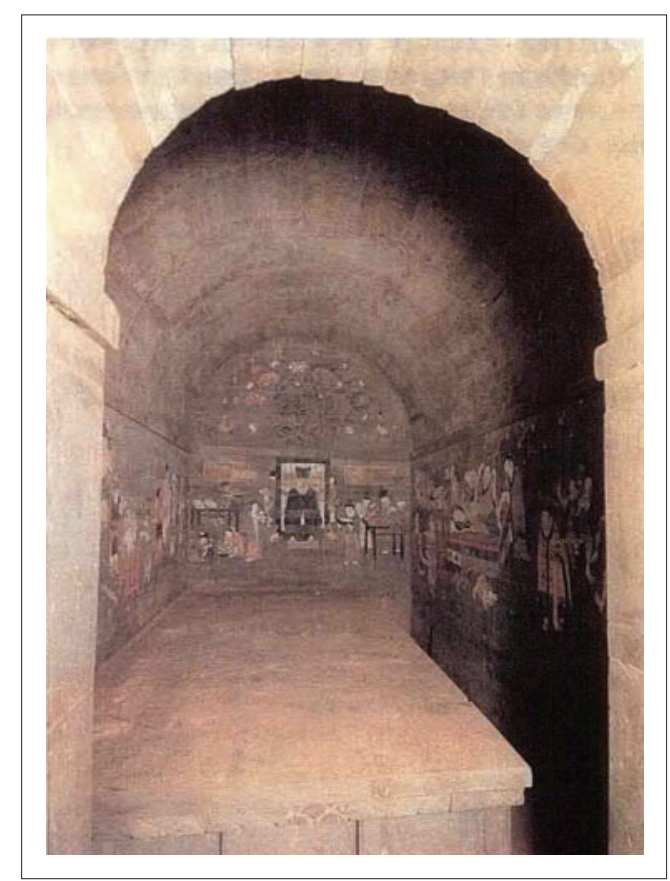

Figure 17.6 Hancheng tomb chamber. ${ }^{\circledR}$ Courtesy of Shaanxi Provincial Institute of Archaeology

hand marked 'Xining yuanbao' 熙寧元寶 (yuanbao was a currency unit), suggesting that she was interred during or not long after the Xining period (1068-77), hence the $c$. 1070 date (Fig. 6).

Two features depart from contemporary Han-Chinese burial practice, causing archaeologists to speculate that the occupants were of west Asian ethnicity. Both wore coarse clothing, and had what reports described as 'red' (hong 紅) or 'yellow' (huang 黃) hair coiled in buns on their heads. Furthermore, other than the coins found in the woman's hand, the tomb, which had remained sealed until its discovery (so the contents should have been intact), contained no grave goods. ${ }^{6}$ Nevertheless, nothing else in the tomb distinguishes it from ethnic-Han practice, and in the absence of other evidence suggesting the relevance of ethnic considerations, the tomb is best read in relation to $c$. 1070 CE north-Chinese burial culture.

As in other tomb murals of the era, many of which show happy domestic scenes and lively entertainments, part of the Hancheng tomb murals' artistry lies in their emotional expressiveness and affective impact. Someone entering the tomb would be confronted first, in ritually central position on the main north wall, with the dynamic and focused activity of the aforementioned pharmaceuticals production workshop. In its midst, they would find the male occupant, seated square and still in an iconic posture of authority. As a man of central importance to the

$6 \quad$ Kang Baocheng and Sun Bingjun 20o9, pp. 79-8o. 


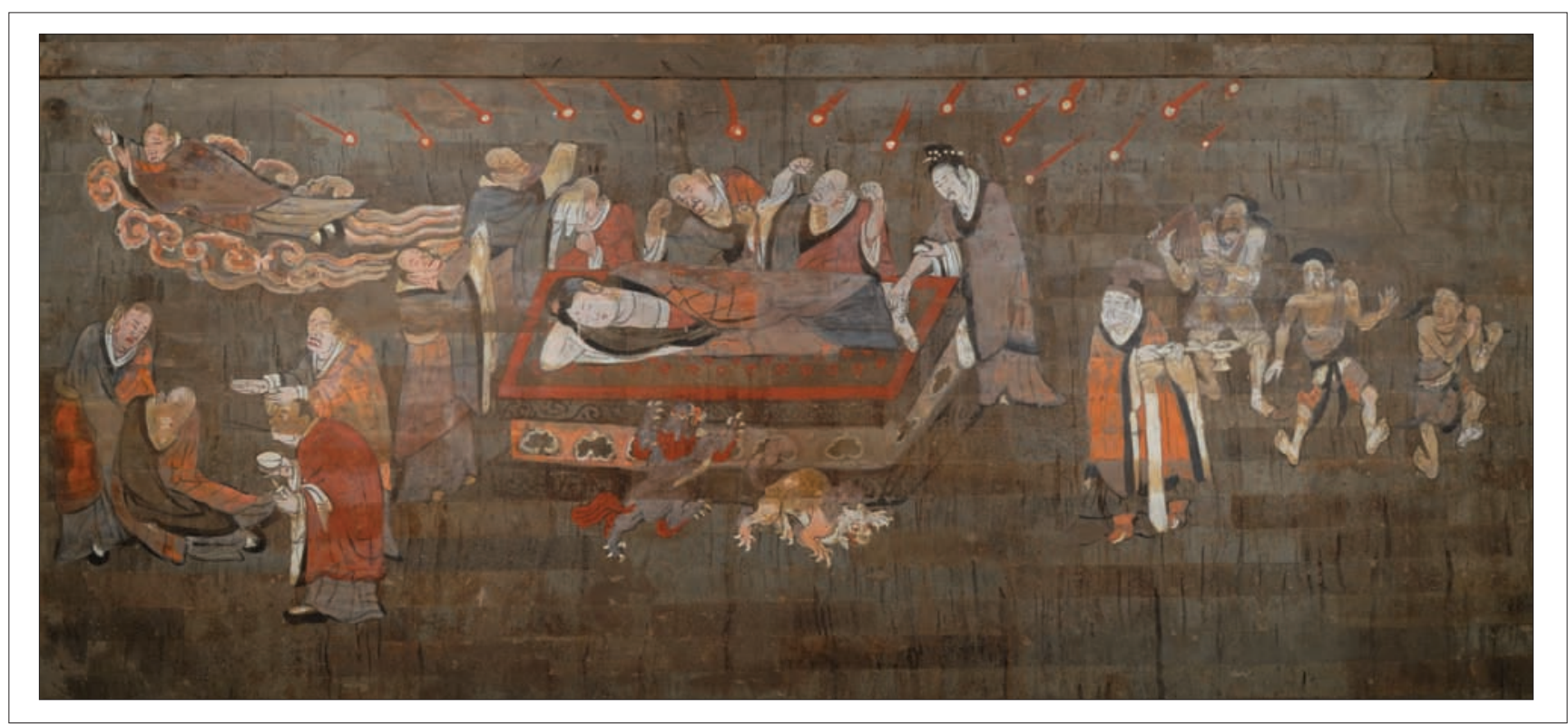

Figure 17.7 Hancheng tomb, east wall mural. Photograph Jeehee Hong

painting and with a status higher than that of the other figures, he is painted larger than the surrounding people. Echoing his calm, an elegant Taihu rock, peony, and crane composition adorns the arch-space above. Turning to the east wall, the viewer is struck by the emotional extremities of mourning. Like the north wall's main figure, the central figure of the reclining, departed Buddha is placid, but his overwhelmed disciples grimace, contort their bodies, beat their chests, flail their arms, and faint in paroxysms of grief. Balancing the lamentations of the eastern wall, the west wall mural of a variety show (zaju 雜劇) evokes raucous mirth, here centring on comic performers surrounded by accompanying musicians (Figs $7-8)^{7}$

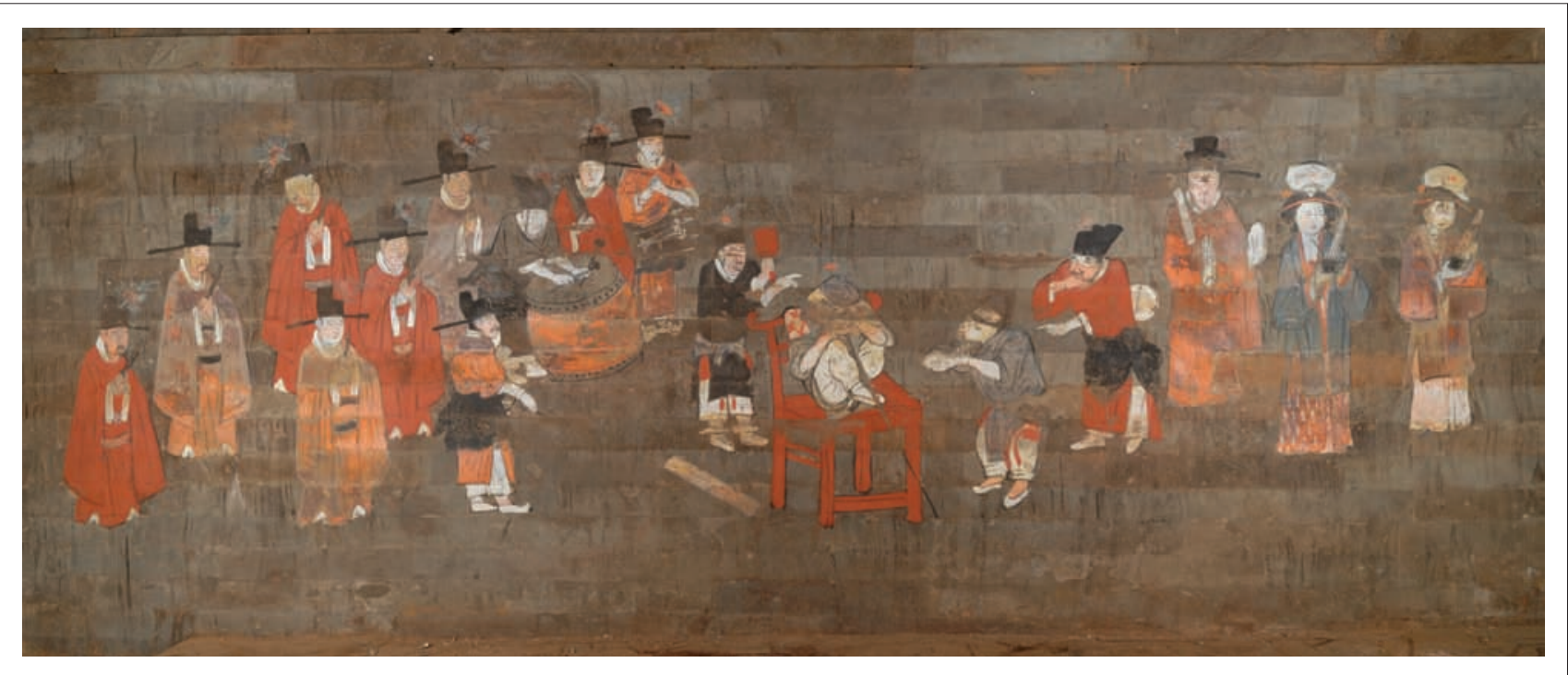

Figure 17.8 Hancheng tomb, west wall mural. Photograph Jeehee Hong

$7 \quad$ For a detailed analysis of the spatial orientation of the murals in relation to the occupants and to each other, and of the tomb and its contents in relation to other contemporary tombs, see Hong and Hinrichs 2015. For identifications of the figures in the nirvana mural and of the comic actor types in the theatrical mural, also see Kang Baocheng and Sun Bingjun 20o9, pp. 84-7. 


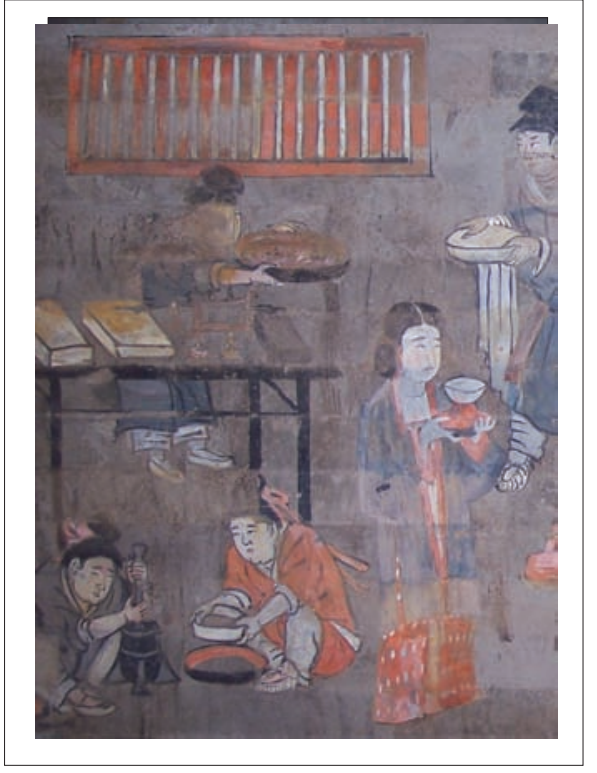

Figure 17.9 Hancheng Tomb, north wall, left side, detail of Fig. 1. ( ) TJ Hinrichs

In the main mural on the north wall, just to the occupant's right, a young woman offers a tea cup, perhaps containing refreshment, but given the context, possibly an herbal decoction for him to test (Fig. 9). Behind her a pair of young men squat on the floor, one grinding medicines with a mortar and pestle, the other sifting the ground herbs into a larger dish. At their back, a rectangular table bears two thick bookcases, brushes slotted into a brush rack, an ink slab, and bottles, presumably for water to make ink. Behind the table, a young man carries a large dish covered with sprays of herbs. In eye contact with him is a man walking out from behind the screen with a cloth draped over his arm and carrying another dish. From the other side of the screen, a young female servant emerges holding a round fan. ${ }^{8}$

As in many portraits from this period and later, a screen provides a backdrop to the occupant. This screen is decorated with a poem in grass script, the first stanza of which expresses a peaceful vision of meditation in a Buddhist temple:

古寺青松老 The ancient temple's verdant pines, so venerable;

高僧白髮長 The eminent monk's white hair, so long.

夜深禪定後 In the depth of night after meditation is fixed,

8 The image of people emerging from out of doorways is found in Han period tombs. Song tombs saw a revival of this and other Han era motifs, which Wu Hung connects to movements among literati to 'follow ancient models'; in the literati case, this entailed austere tombs, but among 'rich landowners in inland regions', it found expression in complex murals and reliefs. Wu Hung 2010, p. 192.
明 $X \times$ 如霜 Bright $X \times$ like frost,

要 $X X X$ Will $X X X X$.

The banal phrasing of this stanza suggests that the author was probably not a literatus, and was perhaps the occupant himself. Nevertheless, whatever its authorship, the poem shows a reaching for literatus-like sensibilities and literary attainments. The second stanza describes unfettered travel through a divine Daoist landscape, and comes from a poem by Lü Dongbin 呂洞賓 (8th century):

琴劍 \{酒棋龍 $\}$ 鶴虎 Zither and sword, \{wine and chess\}, crane, and tiger.

逍遙\{落\}托永無愁 (憂) Freely roaming, dropping out and begging off, forever without worries.

\{閒\}騎白鹿游三島 $\quad$ \{Idly\} riding a white deer, roaming to the Three Isles [of Transcendants].

悶駕青 $\{$ 牛看\}九州 (十洲) Blithely harnessing blue \{oxen to see\} the Nine Provinces (Ten Continents). ${ }^{9}$

By the Northern Song, Lü Dongbin's poetry was circulating widely. He had also become associated in literature with alchemical pursuits, and was an object of worship popular with drug traders, among others. ${ }^{10}$

And the occupant does seem to have been a drug trader. ${ }^{11}$ To the occupant's immediate left stands a boy presenting

9 The words inside ' \{\} ' curly brackets are illegible in the mural, and indicate substitutions from an extant version of the poem; the words inside '()' round brackets are the extant versions of the words underlined. Note that "Nine Provinces" refers to Yu the Great's political division of the realm into administrative territories, while 'Ten Continents' (from the extant version of Lü's poem) is another reference to the world of transcendants. Given the instabilities of textual transmission, it is impossible to know to know whether the tomb mural's version is quoting from or modifying then-circulating models.

The transcription of the Hancheng poem is by Chen Yongzheng 陈永正 of Zhongshan University. See Kang Baocheng and Sun Bingjun 2009, p. 80. For an extant version of Lü's poem, see 'Qiyan' 七言, Quan Tang shi 全唐詩 (Beijing: Zhonghua shuju, 1960), juan 857, p. 9,688.

10 See Baldrian-Hussein 1986, 133-69. I thank Jeehee Hong for pointing out these connections. Hong and Hinrichs 2015.

11 Kang Baocheng and Sun Jianjun inferred from the medical content of the mural that the occupant was a doctor (2009, 81). Certainly, other non-literati tombs, if slightly later, included murals and relief carvings portraying scenes from businesses, for example people reading account books. So while the medical content is unique for a tomb mural, portraying scenes from the occupant's vocation and source of wealth are not, although this mural may be an early example. For related discussions and examples, see Wu Hung 2010, pp. 45-7; and Xu Guangji 2012, vol. 2, p. 164 . 


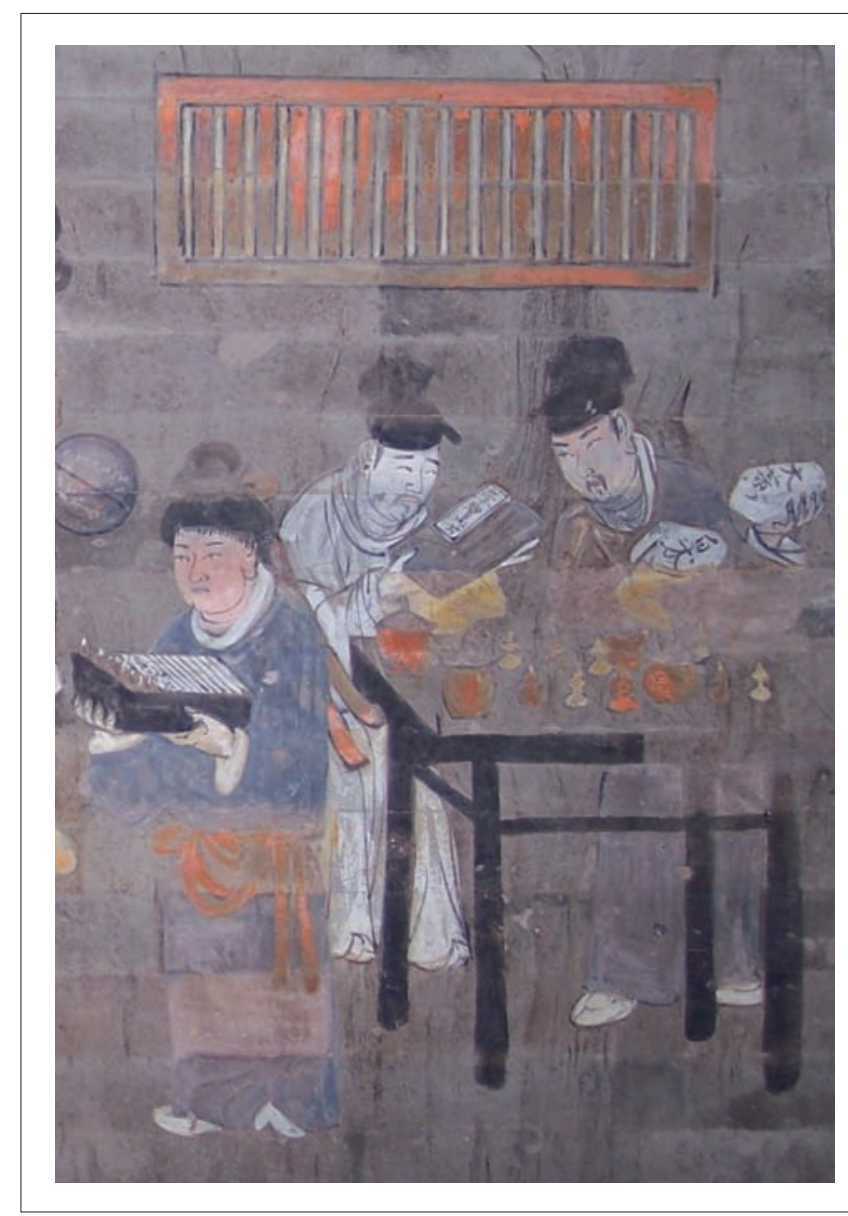

Figure 17.10 Hancheng Tomb, north wall, right side, detail of Fig. 1. (c) TJ Hinrichs

a tray containing three components: out of the top pokes a row of white-stoppered bottles shaped like gourds, long a common form for medicine containers; next the label 'Red Cinnabar Pills' (zhusha wan 朱砂丸); then rows of something white, perhaps paper packaging (Fig. 10).12 Further back is a table covered with a variety of jars and

12 I thank Paul Unschuld for suggesting this identification. 'Perhaps they were formed the same way as their counterparts in Europe. You take a square sheet of paper and fold it from left and right into three identical sections. Then you bend the left and the right sections over the middle section. Now, you fold these three layers again, but this time from the bottom first and then from the top. First, one third from the bottom is folded upwards. This then allows you to take it up, hold it with your left hand and support the lower end with your little finger, keeping the folded lower third in place with your thumb. Then you may pour a powder or pills into the opening on top. Once you have filled the package, you bend the upper third down towards the upward opening of the lower third and insert it into the opening of the lower third that was bent up before. The contents are safely and cheaply stored this way, and they can easily be used by lifting the upper third out of the lower third again.' Email comm., 23 April 2014. gourd-shaped bottles. ${ }^{13}$ Behind the table stand two men, one holding a volume labelled 'Taiping Era Formulas', the other holding white paper packets of a type also common in modern Chinese-style pharmacies, marked with the drug names baizhu 白术 (white Atractylodes) and $d a$ huang 大黃 (rhubarb). ${ }^{14}$ As is common in paintings of human subjects of the period, the people in the painting are shown actively interacting, and these men face each other, apparently consulting about the concoction of a remedy. ${ }^{15}$ This is clearly a workshop for the production of pharmaceutical medicines. Such activity, aimed at the production of medicines to heal others, would have been an appropriately noble activity to portray in a tomb mural (Figs 10-12). ${ }^{16}$

The conjunction of these particular drugs and this book points to the production of a range of disease remedies. In the book, out of a total 16,834 recipes, rhubarb (always specifically Sichuan rhubarb) appears 1,349 times and white Atractylodes appears 941 times, both across a wide range of remedies. ${ }^{17}$ Out of the 941 entries in which the two drugs could potentially appear together, they are combined a total 27 times, just $2.8 \%$ of that total. ${ }^{18}$ The infrequency

13 On the use of the gourd as a symbol for medicine sellers and as a shape for medicine bottles, and for examples, see Unschuld 200o, pp. 48, 79 102, 156, 176, 198.

14 Other roughly contemporary tombs also include labelled books. For example, one of Zhang Shiqing's 張世卿 1116 CE Liao tomb murals include a Buddhist sūtra and the 1oth-century Daoist scripture Changqing jingjing 常清淨經, shown laid out on table in the midst of a domestic tea-making scene. See Wu Hung 2010, p. 232, fig. 227, 228.

15 For further analysis, see Kang Baocheng and Sun Bingjun 20o9, p. 81 .

16 In contrast, the treatment of the occupants' own illnesses would have been a highly inauspicious subject, and therefore one unsuitable for (and unattested in) burial paintings. The instances of bird-bodied Bian Que treating patients as found in Later Han tomb reliefs represent mythistorical episodes, not the occupants' lives.

17 In earlier periods, Atractylodes and rhubarb had been incorporated into some Daoist practices, but in the 11th century, they were much more salient as common therapeutic drugs, both of which wereproduced in Shaanxi, the region of our mural. On the prominence of Atractylodes in Shangqing Daoism, see Stanley-Baker 2013, 175-82. Materia Medica of various periods quote Sun Simiao, and identify the two drugs as being grown in Shaanxi. See Sun Simiao, Qianjin yifang (1959 edn), 2.19, 3.3o.

18 Those combinations appear mainly in juan 11, under Cold Damage or Seasonal Qi (epidemics) complicated by food poisoning or overeating, and under dyspeptic or overeating or drinking conditions, especially those accompanied by constipation or other accumulations (juan 48-51). Although baizhu 白术 (white Atractylodes) and dahuang 大黃 (rhubarb)do not appear to- 


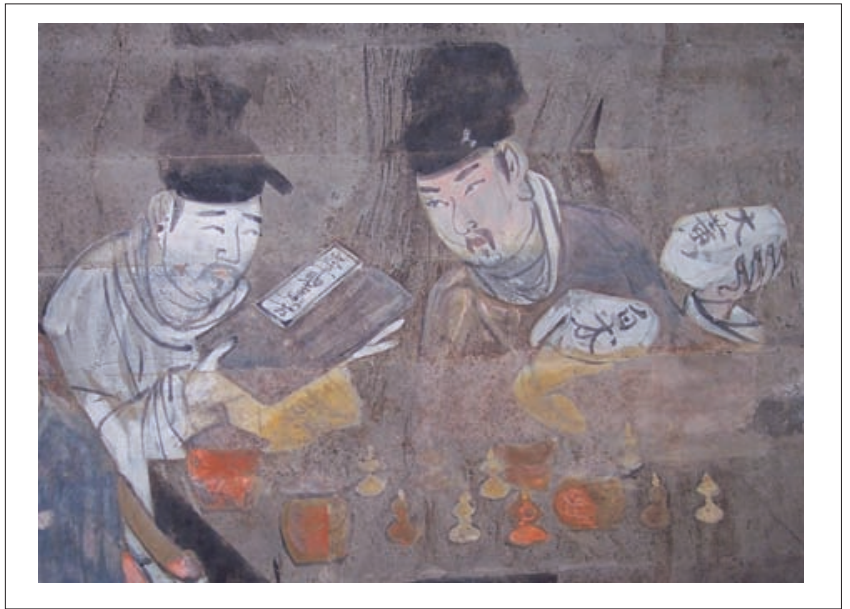

Figure 17.11 'Taiping Era Formulas of Sagely Grace', 'White Atractylodes', 'Rhubarb'. $\odot \mathrm{TJ}$ Hinrichs

of their appearance together is not surprising given that the drugs had contrary effects: Atractylodes treated such conditions as numbness, paralysis, and convulsions; it stopped sweating, fever, violent diarrhoea, and vomiting, and benefited Blood in the lower abdomen. In contrast, far from nourishing abdominal Blood and counteracting diarrhoea and vomiting, rhubarb acted as a purgative that broke up and drained Blood stagnations and blockages along with accumulations and accretions, and cleansed the stomach and intestines. ${ }^{19}$ Marta Hanson has proposed that it is precisely the drugs' incompatibility that explains their function in the mural: as a Yin-Yang pair, standing synecdochically for a full repertoire of drug simples - a reading that agrees with the identification of the mural as representing a workshop that served a sizable clientele. ${ }^{20}$

Reinforcing that interpretation is the inclusion in the mural of the Taiping Era Formulas (Fig. 11). The massive 10o-chapter book collected remedies from physicians throughout the realm, was compiled as a comprehensive reference for medical formulas and disease categories, and was distributed by early Song courts to guide medical relief - i.e., for the treatment of masses of people..$^{21}$ The text was

gether as part of a cinnabar pills remedy, the combination does appear five times in juan 49, which also includes three different versions of cinnabar pills. Chapter 49 focuses on disorders involving accumulations in the abdomen, especially of food that will not disperse. Also see the two drugs combined, for similar conditions, in isolated appearances across juan 6, 9, 14, 16, 38, $43,54,58,71,81-3$.

19 Sun Simiao, Qianjin yifang (1959 edn), 2.19, 3.30.

20 Proposed after joint presentation, with co-author Jeehee Hong, of Hinrichs and Hong 2013.

21 The 100-chapter court-produced formulary was encyclopaedic in scope - the product of Emperor Taizong's call to collect remedies from throughout the realm that would otherwise be trans- so extensive, in fact, that in 1046, Fuzhou 福州 (in Fujian) Prefect Cai Xiang 蔡襄 (1012-67), finding it too unwieldy for everyday use by commoners, commissioned and displayed wood blocks of a much-abridged version, reduced by $60 \%$ to 6,916 entries. ${ }^{22}$ Possession of such an expensive and encyclopaedic work as the Taiping Era Formulas suggests a substantial operation, one that produced standardised remedies for multiple retail outlets, for wholesale markets, for government agencies, or perhaps for some combination of the above.

The division of labour represented in the mural's varied people, activities, and objects also indicates an operation of some scale. All of this points to a functional differentiation of pre-packaged remedies between wholesale production, distribution, and retail (as portrayed in the Qingming scroll), which would in turn have required a certain critical size and level of infrastructure, for example of distribution networks, in commercial pharmaceutical markets. ${ }^{23}$ Around this time, such a division was just appearing in the state's medicinal production and distribution bureaucracy. ${ }^{24}$

mitted only privately within physician lineages, and to organise them in a comprehensive, nosologically indexed reference work. Once it was completed, he ordered two copies distributed to each prefecture, and revived the Tang prefectural post of Medical Erudite (yiboshi 醫博士) specifically to take charge of the text and make it available to commoners for copying. Taizong and some of his successors made concerted efforts to distribute the book. It was compiled under the supervision of Hanlin Medical Officer 翰林醫官使 Wang Huaiyin 王懷隱. Sections on disorders open with analyses drawn from Chao Yuanfang's 巢元 方 Zhubing yuanhou zonglun 諸病源候總論 (Comprehensive Treatise on the Origins and Symptoms of Diseases, 610 CE). See Okanishi Tameto 1969, pp. 713-20. On later efforts to further distribute the work, see Hinrichs in Chia and de Weerdt 2011, pp. 218-19.

22 Okanishi Tameto 1969, pp. 720-21. In contrast to the Taiping Era Formulas, about the time of the tomb or a little later, the state produced a formulary specifically designed for daily application, to guide medical relief by the Imperial Medical Service and the production of pre-packaged drugs by the Pharmacy Service. This book was the Taiyiju fang 太醫局方 (Formulas of the Imperial Medical Service), published in the Yuanfeng Period (1078-85), and was only a modest 1o juan in length. The revised edition of the Taiyiju fang, the Taiping huimin hejiju fang 太平惠民和劑 局方 (Formulas of the Pharmacy Service for Great Peace and for the Benefit of the People, 1107), circulated widely. See Okanishi Tameto 1969, pp. 748, 765-87.

23 There had been a geographically widespread market at least for drug simples for some centuries. See Stanley-Baker 2013; Shiba Yoshinobu 1970, p. 49.

24 There was a separate Office for Compounding Drugs (Heyao suo 合藥所) in operation by 1075, and in 1076 Shenzong's court 


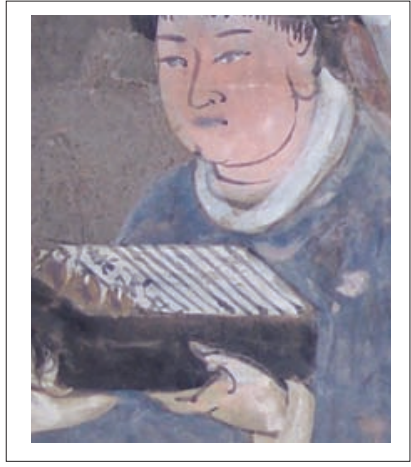

Figure 17.12 'Cinnabar Pills', detail of Fig. 1. ${ }^{\odot}$ TJ Hinrichs

Returning to the mural, the cinnabar pills being offered to the occupant may represent a more complex intersection between the personal and the public (Fig. 12). As an item stocked for sale, cinnabar's popular connotation of powerful life-giving properties would have made 'Cinnabar Pills' a marketable name; beyond that, as in the case of atractylodes and rhubarb, it is impossible to pinpoint a specific application. The term 'Cinnabar Pills' was apparently marketable enough to have named a heterogeneous variety of remedies in the diverse physicians' repertoires that went into the compilation of the Taiping Era Formulas. That book included a total 49 recipes for Cinnabar Pills with 49 different combinations of ingredients, spread fairly evenly throughout. Forty-eight of the 49 formulas treated such ailments as Wind disorders in the Heart Visceral System, various types of epidemic fevers, appetite loss, and demonic intrusions. ${ }^{25}$

The 49th 'Cinnabar Pills' formula, along with the position of the pills in the mural, suggests other layers of meaning. The tray of bottles and packages carrying the label 'Cinnabar Pills' appears, in the setting of the workshop, to be offered to the occupant for his inspection, perhaps to check for quality. In the context of the burial, the pills may also represent a gift to the deceased, not to treat something so unpropitious as illness, but representing descendants' hopes for his long and robust afterlife. ${ }^{26}$ In the Taiping Era

merged it with related facilities and a new Pharmacy Service (Maiyao suo 賣藥所, later Heji ju 和劑局). When Huizong's court expanded the Pharmacy Service, they also instituted separate facilities for drug manufacture and sales. See Li Tao, Xu zizhi tongjian changbian (1986 edn), 271.14A, 275.6B; Goldschmidt 2009, pp. 125-30.

25 I thank Chen Shiau-Yun for double-checking these calculations with Academia Sinica's Hanji dianzi wenxian 中央研究院漢籍 電子文獻 database.

While in some Daoist practice, the mineral could be involved in the alchemical pursuit of transcendence, more commonly and popularly, it seems to have possessed associations with the extension of life. In the 978 collection of tales Taiping guangji 太
Formulas, the 49th Cinnabar Pills entry appeared as the first item in chapter 98, on 'Supplementation and Boosting' (buyi 補益), and that recipe was not a treatment for disease but a tonic for long life:

Cures the hundred [i.e., all] ailments, benefits the Five Visceral [Systems], quiets the Yang-soul (hun 魂) and settles the Yin-soul ( $p o$ 魄), nurtures the Heart and expands Qi, and gives pleasant lustre to the face. Taken over a long time [the pills] will lighten the body, extend the years without aging, lengthen the sinews, supplement the Cinnabar Fields (dantian 丹田), sharpen hearing and sight, and [impart] much skill and strength. ${ }^{27}$

'Cinnabar Fields' refers to loci in the head, chest, and lower abdomen in Daoist bodily landscapes. In general, in Tang and Song medical formularies, distinctively Daoist terminology such as 'Cinnabar Fields' tends to appear in relation to remedies that are either apotropaic, exorcistic, or for 'nurturing life' (yangsheng), at least in the loose sense of 'supplementation and boosting.' ${ }^{28}$

We must remember that such analytic distinctions, between Daoism and medicine, may have been neither salient nor sensible to the occupants and their family. While some Song figures did advocate distinguishing and then removing Daoist elements from medical works, and while, generically, Daoist and medical writings and practice remained discernibly different, the type of boundary work that produced and policed such differences was clearly not of interest to our tomb occupant. ${ }^{29}$ From the point

平廣記, zhusha appears occasionally as a substance ingested for the extension of life, but not for the goal of transcendence. $\mathrm{Li}$ Fang et al., eds [1961] 1981, zhusha: 1.6, 52.321, 237.1824, 437.3896.

27 Wang Huaiyin et al., Taiping shenghui fang ([1958] 1982 edn), juan 98, p. 3,130. Rhubarb pills (大黄丸) appear toward the end of the same chapter, and are identified with more mundane therapeutic actions: 'Harmonising and benefiting the diaphragm, expelling stagnations, pushing what is stale and extending what is fresh, and dispersing Wind and flowing with Qi'. Wang Huaiyin et al., Taiping shenghui fang ([1958] 1982 edn), juan 98, pp. 3,153-4. In this chapter, Atractylodes, so prominent in Shangqing Daoism, only makes the odd appearance in formulas as a subsidiary drug.

28 See, for example, Hinrichs 2003, Appendix 5: 'Prescriptions for Avoiding Warmth and Contagion from Sun Simiao's Beiji qianjin yaofang and Pang Anshi's Shanghan zongbinglun', pp. 251-69.

29 As examples of medical boundary work, Cai Xiang specifically ordered the excision of 'passages on acquiring immortality' from his abridgement of Taiping Era Formulas, for reasons of practicality for commoners. Some decades later, Cheng Jiong (fl. 1163-1176) wrote an entire book calling for the restoration of medicine to canonical foundations, and specifically attacked the use of Daoist physiological terminology. See Hinrichs 2003, pp. 36,215 . 
of view of a modern scholar or of certain Northern Song specialists, just as some parts of the Taiping Era Formulas fold Daoist elements into the field of medicine, so too the mural on the tomb's north wall layers medicine in daily life with medicine in the afterlife. In the same vein, the screen poem combines Daoist with Buddhist elements, and the medical and Daoist content of the northern mural sits between Buddha's nirvana to the east and entertainment to the west. To separate those epistemological, ontological, and salvational realms, though, would have been atypical of the 'eclectic' non-official tomb culture in the Song.

The tomb as a whole and the activity of the north mural in particular, revolve around the male occupant, a structuring of authority in which the patriarch, as object of veneration, occupies a position homologous to that of the ruler. Like the ruler, the occupant sits squarely and centrally, facing south. Just as, in ideal classical formulations, the ruler orders All-Under-Heaven and the Enterprise (ye 業) of state, not through action of his own but through the effects of his potency on others, so too the patriarch orders his family (implicitly present, ritually facing him and organising rituals at the tomb) and his commercial enterprise $(y e) .^{30}$

The Hancheng tomb's north wall mural is a rare primary source, coming as it does from a merchant family's tomb and not a physician's or literatus' brush, on the place of pharmaceutical production in the life of an 11th-century commoner. In official sources regarding the book, we get decrees giving general orders for the Taiping Era Formulas' production and distribution, and for the establishment of positions charged with its 'handling'. In Cai Xiang's preface to his abridged version of the Taiping Era Formulas, we hear that, despite Taizong's order that the book be 'distributed to the prefectures for transmission to the officials and the people', in most prefectures it was just 'strictly locked away, reverently sunned and aired, and that is all. None of the officials or the people gained benefit from it'. ${ }^{31}$

In other sources, we learn that some imprints of the book were riddled with errors, the fault of unruly or lazy woodblock engravers. ${ }^{32}$ In our tomb mural, we can see the

'One who governs through Virtue ( $d e$ 德) is like the Pole Star. It occupies its place while the host of other stars pay homage to it. 'The virtue of the Noble Man is like the wind, and the virtue of the small people is like grass. When the wind blows over the grass, the grass must bend.' 'To rule through non-action, such was [the sage ruler] Shun. How did he do it? He made himself reverent and exactly faced south, and that is all.' Lunyu 2.1, 12.19, 15.5 .

31 Quoted, with minor alterations, from Hinrichs in Chia and de Weerdt 2011, p. 234. importance of the text to a merchant's life, as an instrument that contributed to his flourishing pharmaceuticals operation, and as an expensive, luxury object that garnered some of the state's glamour for him and for his family.

In the tomb mural image of the Taiping Era Formulas of Sagely [i.e., Confucian-Imperial] Grace, we see a trace of state medical publishing serving as means of livelihood and as a point of pride in the life of a provincial commoner. For Song courts and civil officials, the book served efforts to care for and educate commoners, and thereby ground the regime's legitimacy. Taizong had ordered the Taiping Era Formulas to be printed and distributed, two copies to each prefecture, both to spread medical knowledge and to guide medical relief. Cai Xiang had commissioned the book's abridged version, whose woodblocks he had posted on the Fuzhou Yamen gates,

in order to guide the Sagely Ruler's inexhaustible grace of morality to penetrate to those below, and also to enlighten people of the error of relying on shamans, and to cause them to return to constant standards. ${ }^{33}$

Taizong's medical publishing, education, and relief policies were just a few of such programmes, which saw unprecedented expansions under the Song. Similarly, Cai's was one of numerous campaigns and imperial decrees aimed at rectifying southern healing practices, often targeting indigenous 'shamanic' healers. ${ }^{34}$ And these programmes of medical governance were part of more general movements among Song courts and civil officials that - like reinterpretations of ancient forms seen in Song tomb mural motifs - reinterpreted Mencian ideals to more deeply root imperial legitimacy in the well-being of commoners, and gave new forms to Xunzian ideals of 'transforming [commoner] customs and mores through education' (jiaohua fengsu 教化風俗). ${ }^{35}$
33 Hinrichs in Jia and de Weerdt 2011, p. 235.

34 For a study of these campaigns, see Hinrichs 2003. The term $w u$ 巫, translated here as 'shamanic', appeared in these official documents as an etic term, and referred generally to the shrine officiants and healers indigenous to diverse southern peoples. On Song re-orientations of sovereignty toward commoners and on the ways in which those views of sovereignty became visualised in paintings, see Powers in Porter 2012, pp. 226-36. On Song policies to 'transform [commoner healing] customs through [medical] education', see Hinrichs in Chia and de Weerdt 2o11, pp. $233-8$. 


\section{Making Commoners Visible at Court}

In the Qingming Scroll and Moxibustion, Zhang Zeduan and Li Tang projected particular inflections of imperial ideology as it related to medicine in commoner lives and livelihoods. The Song state had given qualitatively new, specific, practical, and material forms to medicine-as-ideology, making medicine a more integral and prominent part of governance, and deploying it - as medical relief, medical education, and as healing reform - as a means of actively extending the state's morally transformative power into communities, homes, and bodies. Scholars have shown the ways in which Han ideologies inscribed the imperial bureaucracy on the cosmos, and Han medicine in turn inscribed it on the body. ${ }^{36}$ Han medicine thus held the potential to powerfully naturalise the state at the level of lived experience.

More than any state before it, the Song availed itself of that ideological resource. In addition to imperial formularies such as the Taiping Era Formulas, and the compilation and publication of various Materia Medica, between 1057 and 1069 the Song's Bureau for Editing Medical Treatises (Jiaozheng yishu ju 校正醫書局) canonised and disseminated state-naturalising physiologies and medical treatments through the publication of authoritative editions of the medical classics. ${ }^{37}$ Besides officially recognising and quantitatively expanding the reach of these texts and the ideas they contained, the Song state furthermore tied medicine to the classical Confucian missions of caring for commoners' lives (medical relief) and transforming customs and mores through instruction (reforming southern healing customs and distributing medical texts).

We can see the new visibility of commoners to court and to scholar-officials in a vogue for paintings and poetry that depicted idyllic commoner lives. Recurring themes included village weddings and festival celebrations, and their embodiments of the 'authentic' essence of canonical ritual and human relations; and the classically normative modes of commoner productivity (and contribution, through taxation, to the political economy), agriculture and weaving. ${ }^{38}$ Some court paintings also celebrated livelihoods that, while classically denigrated, had become more economically important to the Song state, i.e., commerce. ${ }^{39}$ And in both

\footnotetext{
36 See, for example, Unschuld 1985, pp. 79-83; Sivin 1995, pp. 5-37; Lewis 2006, pp. 37-47.

$37 \quad$ Hinrichs in Jia and de Weerdt 2011.

38 Hammers 2011; Cheng Wen-chien 2011, pp. 67-106; Cheng Wen-chien 2005, pp. 309-57; Hartman 1995, pp. 1-72; Deng 2005, pp. $125-45$.

Powers 2012, pp. 232-3.
}

the Qingming Scroll and Moxibustion, we find medicine, an area on which Song courts and officials focused great energy and scrutiny.

\section{Qingming on the River}

There is some uncertainty surrounding the dating of Zhang Zeduan's painting of commoner daily life, Qingming on the River, but good evidence points to it having been produced at Huizong's court. ${ }^{40}$ Huizong's was a court that brought new vigour to building institutions aimed at elevating and at the same time unifying literati and technical learning and commoner customs, and caring for commoner welfare. ${ }^{41}$ Huizong connected all of these concerns with the need to improve the quality of medical studies:

We grieve for the blockage of the Great Way, for the [unhealthy] practices entrenched in prevailing customs, for the inveterate bad habits [and chronic ailments] that mire our commoners, and for the reckless doings of mediocre doctors, whose learning lacks profundity and erudition, and whose knowledge lacks insight and analytic comprehension. ${ }^{42}$

In aid of advancing and unifying medical knowledge, the court expanded the Medical School system and extended it to the provinces, and undertook new medical book publishing projects. For commoner welfare, the court also expanded the imperial Poorhouse system and Pharmacy Service, and created state-run Pauper's Cemeteries and Charity Hospitals. ${ }^{43}$ The Qingming Scroll celebrates the desired effects of such policies, even though it only hints at the existence of the programmes themselves.

The name of the scroll, Qingming on the River, refers not to the Qingming festival, but to the month of Qingming, an auspicious season of growth, and simultaneously to the peaceful and prosperous times produced by good governance, the latter a reference to Shijing 詩經 (Classic of Songs, also translated Book of Odes). ${ }^{44}$ Accordingly, the painting exudes prosperity, exuberance, and social vitality. Features such as the painting's several wine shops suggest not just adequate livelihood but plenitude, with space for

On the dating of the scroll, see Murray 1997, pp. 102-5.

41 On Huizong's goals for commoner customs, see for example his 1112 palace examination question, Bol 2006, pp. 195-6.

42 Zhao Ji Shengji zonglu, Preface ([1962 1992 edn] $)$, vol. 1, 3 .

43 For an outline of Huizong's broader set of reforms and institutional innovations, and the place of welfare and medical relief within those, see Chaffee in Ebrey and Bickford 20o6, pp. $37 \mathrm{ff}$. For an overview of Huizong's work in medical education, publication, and medical relief, see Ebrey 2014, pp. 191-4; Goldschmidt 2006, pp. 275-323. de Pee 2010, p. 167 , n. 6 o. 


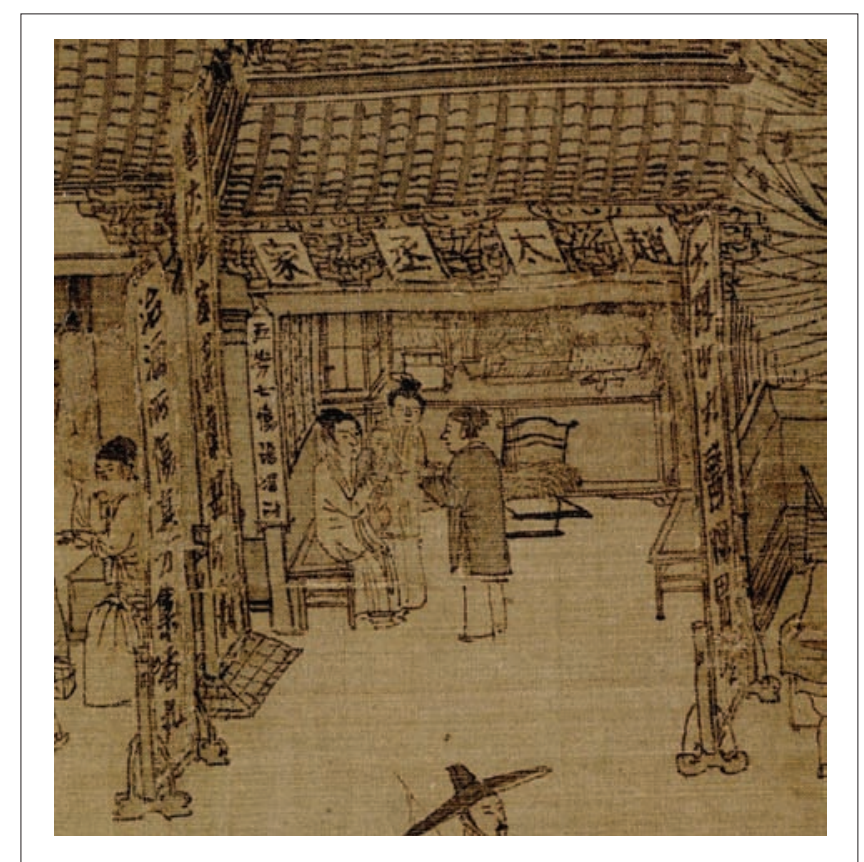

Figure 17.13 Qingming on the River, detail of Fig. 2. ${ }^{\odot}$ Courtesy of Palace Museum, Beijing

leisurely socialising. ${ }^{45}$ The flow of human motion and activity, from the countryside into the city, teems with intriguing people and happenings, the most dramatic of which is a boat broken from its moorings, which attracts crowds on a bridge and nearby riverbanks to gawk and also to help re-tether the vessel. The scroll is full of vibrant everyday life, excitement, collective work and play, and the occasional manageable and non-life-threatening drama easily resolved through community cooperation.

Following the flow of action from the countryside into the city, one block inside the city wall we find a pharmacy open to the street. (Fig. 13). ${ }^{46}$ The pharmacy's advertisements continue the scroll's larger themes of abundance: one of the shop's placards echoes the theme of liberal drinking with the advertisement: 'Cure the Damage of Wine: Authentic-Recipe Collected Fragrance Pills' (Zhi jiu suo shang zhenfang jixiang wan 治酒所傷真方集香 丸). Another sign refers to disorders of the stomach and intestine (changwei bing 腸胃病), also evoking ample and rich eating. A smaller forward-facing sign advertises remedies for the 'Five Over-exertions and Seven Injuries' (wulao qishang 五勞七傷), ailments mainly of overindulgence and overwork. ${ }^{47}$

45 Zhou Baozhu 1997, pp. 95-104.

46 There is another establishment around the corner, with signs just visible and reading 'Yang Family Clinic' and 'Dr Yang' (yangjia yingzheng 楊家應症; Yang daifu 楊大夫....). For the reading of these and other signs, I follow Zhou Baozhu 1997, p. 88.
In contrast to the themes of these signs, which point to busy lives and boisterous socialising, the human scene in the pharmacy itself is a serene one - an island of tranquillity on a bustling street. Inside we see a pharmacist/doctor quietly examining a small child held on his mother's lap, with a female servant standing to their side. The scene points to the domestic matter of child-rearing, and to a household that could afford a servant. Like the other mini-dramas woven throughout the scroll, this one is non-critical: the child shows no signs of distress, being well enough to be brought to the pharmacy and to sit comfortably upright.

The scroll as a whole in fact reveals no direct signs of official activity, no government offices, no officials parading or inspecting, no apparent policing. As for the greatest preoccupation of Song medical governance, epidemic relief, the small shop advertises no remedies for such ailments. ${ }^{48}$ There are, however, indirect hints at official connections. For example, Tsao Hsingyuan has argued that figures in the scroll hiding their faces with round fans depict incognito

ied between (and even within) medical texts. The Taiping Era Formulas of Sagely Grace followed the nosological work Comprehensive Treatise on the Origins and Symptoms of Diseases (Zhubing yuanhou lun 諸病源候論), with the Five Overexertions as those of will (zhilao 志勞), of thought (silao 思勞), of heart/mind (xinlao 心勞), of worry (youlao 憂勞), and emaciation (shoulao 瘦勞). It includes two sets of 'Seven Injuries', the first having to do with various Yin (male sexual, urogenital, colorectal) problems: Yin (given context, meaning genital) Cold (yinhan 陰寒), Yin atrophy or withering (inability to get an erection) (yinwei 陰萎), painful and urgent diarrhoea (liji 裡 急), frequent seminal emissions (jinglianlian 精連連), paltry semen and damp genitals (jingshao yinxiashi 精少陰下濕), clear, cold semen (jingqing 精清), and painful and frequent urination (xiaobian kushu 小便苦數). The second set of Seven Injuries includes damage to the five Yin visceral systems, skin, and will (zhi 志) from overeating; from strong anger; from the exertion of lifting something heavy; from drinking something cold when already cold; from anxiety and over-thinking; from exposure to wind, rain, and cold; and from immoderate fear. Wang Huaiyin et al., Taiping shenghui fang ([1958] 1982 edn), juan 26, p. 748. Also see Chao Yuanfang Zhubing yuanhou lun jiaozhu 諸病源候 論校注, ed. Ding Guangdi et al. 1991, juan 3, pp. 88-9o.

48 For example, Huizong's 20o-chapter Shengji zonglu 聖濟總錄 (Comprehensive Record of Sagely Beneficence, $1118 \mathrm{CE}$ ) opens with two chapters on the application of Five Circulatory Phases and Six Climatic Influences (wuyun liuqi 五運六氣) theories to the prognostication of 'commoner diseases (minbing 民病)' i.e., epidemics.

Asaf Goldschmidt argues that epidemics were a major driving force behind Song state interest in medicine in general, and epidemic Cold Damage disorders and wuyun liuqi theorisation in particular. See Goldschmidt 2009, pp. 69-102. 
scholar officials. ${ }^{49}$ And while the pharmacy itself does not sport the title of the Pharmacy Service, and is too small to be a government operation, the pharmacy does refer to state medical institutions in two of its signs. The sign that ends with 'stomach and intestine disorders' begins with 'Pills Issued by the Imperial Medical Service' (Taiyi chu wan 太醫出丸). A sign hanging horizontally over the main entryway identifies the place as 'Shop of Imperial [Medical Service] Director Zhao' (Zhao Taicheng jia 趙太丞家). ${ }^{50}$

Just as the Hancheng mural celebrates the occupant's achievements and authority by positioning him as an unmoving nexus of activity, so does the Qingming Scroll pay tribute not to Huizong's acts, to his institutions themselves, but to their desired effects, to happy, simple, and abundant commoner lives. The scroll does, with its self-effacing officials and its former medical officer working commercially, suggest effects overflowing from direct official acts - a pole apart from such remedial governance as poor relief. Along with the vibrant life depicted throughout the rest of the painting, the unruffled child-patient (apparently not urgently sick, but yet seeing a physician), the remedies not for epidemics (the usual object of official medical relief) but for overindulgence - all speak to a measure of bounty beyond sufficiency, and to imperial potency and virtue propagating well beyond the palace and government compounds.

\section{Moxibustion}

In contrast to the Qingming Scroll, and in accord with the tenor of its own times (c.1130-50), Moxibustion eschews any reference to government agency. ${ }^{51}$ By then, Huizong's

49 Tsao Hsingyuan 2003, pp. 166-7.

50 An abbreviation for Taiyiju cheng 太醫局丞, also abbreviated Taiyi cheng 太醫丞, a position in charge of the Imperial Medical Service, established during the Xining period (1068-77) and continued into the Southern Song. Gong Yanming 1997, pp. 284-5. Pharmacy shops opened by former medical officials are attested in 12th-century sources. One of the pharmacy shops (yaopu 藥鋪) listed in the account of the Eastern Capital, Dongjing menghua lu 東京夢華錄, includes such a medical official's title in its name, and other sources describe former medical officials opening pharmacy shops both in their hometowns and in the capital after retirement. See Meng Yuanlao, Dongjing menghua lu (1980 edn), 3.18; Hong Mai Yijianzhi (1981 edn), 夷堅支乙志 7 , p. 845 .

$51 \quad$ Li Tang was styled Xigu 晞古 and was a person of Heyang sancheng in Meng District, Henan (孟縣河陽三城). He served in the Painting Academy (Huayuan 畫院) under Huizong. He fled the Jurchen invasion to Lin'an (Hangzhou), and after a period of living in poverty from the sales of his paintings, was re-appointed to the Painting Academy during the Jianyan period $(1127-30)$. His dates are uncertain and sources disagree, but he is

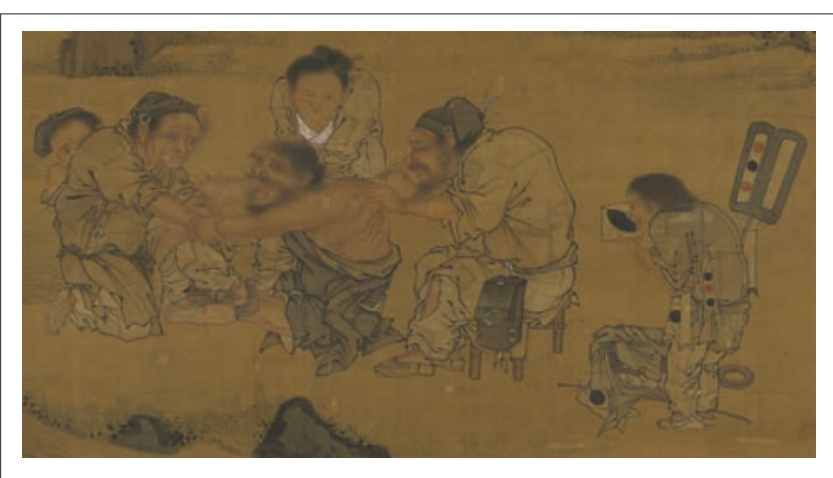

Figure 17.14 Compassion in Moxibustion, detail of Fig. 3. ${ }^{\circ}$ Courtesy of National Palace Museum, Taipei

grandiose ambitions to create a flourishing, unified, and vigorous society through centrally governed institutions had been thwarted, not only by the challenges of bureaucratic implementation, but by catastrophic collapse and disgrace. In 1126, the north-eastern Jin regime 金 (1115-1234) armies invaded Song, prompting Huizong to abdicate. A year later the Jin captured Huizong, the reigning Emperor Qinzong 欽宗 (r. 1126), much of the court, and a large swathe of northern territories. Song refugees regrouped in the south, founding a new 'temporary' capital at Hangzhou, and enthroned one of Huizong's sons as Emperor Gaozong. In the Southern Song (96o-1279), as it came to be called, many blamed the loss of the northern heartland on Huizong and his policies. Thus, in its retrenchment and reorganisation of the government, Gaozong's court eliminated some of Huizong's expensive and government-expanding programmes, including those for medical and poor relief. Where, in the Northern Song, literati of all factions had tended to talk about social transformation in relation to centralised government policies, Southern Song intellectuals advocated reform through extra-official local activism.

Nevertheless, while the Southern Song state scaled back the radical institutional innovations of the pre-invasion era, medical governance, which had become so prominent in the Song's first 16 o years, retained some of its institutional and ideological hold. Despite the crisis of war with the Jin continuing until 1142, and notwithstanding the expense of tribute paid by the Song to the Jin thereafter, medical care for commoners did not drop entirely from official view. In 1136 Gaozong revived the Pharmacy Service, and in 1151 he expanded the network of pharmacies, now called 'Great Peace Bureaus for Benefiting the Common People' (Taiping huimin ju 太平惠民局), to its greatest extent to

generally thought to have died before 1050. On attribution and dating, see Ni Zaiqin 1991, pp. 3-5; Tong Wene 童文娥, 'Jiuai tu' 炎艾圖, in Guoli gugong bowuyuan 2010, p. 389 . 
date, mandating one in each prefecture. ${ }^{52}$ And although official policies to reform southern healing customs and shamans never reached the levels that they had in the Song's first century, Gaozong's court, located in a region formerly targeted in earlier campaigns, made its own forays against southern shamans and their unorthodox approaches to disease. ${ }^{53}$ Not long after Gaozong's time, scholar-official Cheng Jiong 程迥 ( $f l$. 1163-74), railing against shaman healers in the south, commented wistfully: 'The people of the central plains [the lost northern heartland] trust in physicians and do not trust in shamans. ${ }^{54}$

It is just such norms, trust in physicians (and not in shamans), that Moxibustion portrays (Fig. 14). In it, we find a doctor calmly applying a cone of moxa, glowing red and smoking, to a man's bare back. Behind him, a young assistant prepares a poultice to apply to the patient's moxa blister. We can see from the doctor's accoutrements - his stool, his medical kit and bags hanging from his belt and on the ground, and signs with black and red circles advertising his vocation - that he is an itinerant healer. ${ }^{55}$ Besides his kind face, the doctor's coarse, torn, and multiply patched clothing, by suggesting that he does not profit greatly from his treatments, indicates his decency, and distinguishes him from supposedly venal 'shamans' or self-aggrandising charlatans.

The setting and grouping of the figures in the painting also contrasts sharply with literati complaints about southern shamanic healing customs. Scholar-officials singled out for special condemnation the quarantine of the sick in darkened rooms, isolated from family and relegated to the care of 'shamans'. ${ }^{66}$ The issue remained alive in the Southern Song, prompting the aforementioned Cheng Jiong to write an entire book against theories of contagion, which he blamed for helping perpetuate such noxious customs. ${ }^{57}$ The Moxibustion patient, far from sickroom seclusion and shamans' exorcistic intervention, is treated in the sunshine, outside the village wall, surrounded by

52 Xu Song, Song huiyao jigao (1936 edn), zhiguan 職官, 27.66A, $67 \mathrm{~A}$.

See, for example, Gaozong's edicts to control and prohibit shamans who promote 'human-killing and demon-worshipping' in 1142 and 1153, and shamanic healers who prevent commoners from seeking medical care in 1146. In addition, note various campaigns by local officials against shamans under Gaozong. Listed in Wong Cheung Wai 2005, pp. 268, 274-5. For another example of spots being used as a sign for a plaster medicine seller, and for images of plaster medicines, see Unschuld 200o, pp. 45, 47, 79 .

$56 \quad$ See Hinrichs 2003 , ch. 7 .

57 See Hinrichs 2015. and in close physical contact not only with the doctor but with family. As the restorative moxa burns and the patient grimaces and yells, his family express their sympathy with furrowed brows and wincing faces, and help him endure the pain and hold still by tightly gripping his arms and by pinioning his legs with their own feet. Providing some comic relief, on the far left, a child nervously peers around the older woman, and on the far right the doctor's apprentice, inured to such scenes, grins.

As a court painting that celebrates the emperor's ability to establish good commoner customs and mores, Moxibustion spotlights simple, mutually-caring folk, a close-knit family, and a canonically-endorsed mode of healing. In this painting, the state is an assumed, not a marked presence. While Gaozong did continue and even expand the Pharmacy Service, his was not a time for bringing attention to state institution-building or growth. The painting embodies an ideal of imperial efficacy and authority closer to that of classic non-action (wuwei 無爲), a state in which great harmony and stability is achieved with, and precisely because of, minimal state intervention - a restoration of such foundational Confucian ideals as that of the ruler who rectifies himself, faces south, and thereby (and not through centralised institutional apparatuses) transforms the people. ${ }^{58}$

\section{Conclusion}

The three paintings share a vision of patriarchal and imperial authority as a pivot generative of positive human relations. The Hancheng tomb mural situates the merchant in the centre, larger-scale, solidly-sitting, iconically outward-facing. Court paintings assume greater imperial presences: in the Qingming Scroll, hinted at through references to government organs and officials; in Moxibustion, veiled, a pivot operating smoothly-silent and invisible. Despite their stillness and non-action, those

58 'One who governs through Virtue $(d e)$ is like the Pole Star. It occupies its place while the host of other stars pay homage to it.' 'Guide [the people] by means of rules and order them ( $q i$ 齊) [literally, make them uniform] through punishments, and the people will evade [your governance] and will lack any sense of shame. Guide them through virtue and order them through rites, and they will have a sense of shame and will also regulate themselves.' 'The virtue of the Noble Man is like the wind, and the virtue of the small people is like grass. When the wind blows over the grass, the grass must bend.' 'To rule through non-action, such was [the sage ruler] Shun. How did he do it? He made himself reverent and exactly faced south, and that is all.' Lunyu 2.1, $2.3,15 \cdot 4,12.19$ 
patrons' agency, productive of medical production and collaboration, is certain. It is the Hancheng merchant who built the prosperous workshop; it is Huizong who revived and sponsored new medical institutions in his dream of a thriving realm; and it is Gaozong who saved the dynasty and preserved imagined classically-conforming social norms of the Han heartland in the ethnically-mixed south.

There are good reasons why it is the Song period that produced these three paintings. It is in the 1oth and 11th centuries that affluent commoners began building tombs decorated with murals that showed aspects of their daily lives. And the pharmaceuticals trade and government-published medical texts had by then become significant sources of commoner wealth and prestige (at least for our Hancheng merchant). In turn, Song courts invested enough of their legitimacy in the quality of commoner daily life and in medicine to make the two themes and their conjunction fitting subjects for imperial paintings.

As paintings, the three objects celebrate their patrons' social and medical efficacy in ways that texts did perhaps less well, and less strikingly. Where a eulogy might praise the achievements of the departed man in building a pharmaceutical business, a tomb mural can display a conception of him as the stable, authoritative centre of the diverse activities that went into medicinals production..${ }^{59}$ Various edicts proclaimed imperial intent to rectify commoner healing customs, and Huizong's Comprehensive Record of Sagely Beneficence and Gaozong's reinstatement of the 'Great Peace Bureaus for Benefiting the Common People' both proclaimed imperial benevolence through medicine. The Qingming Scroll and Moxibustion, though, reveal visions of imperial benevolence actually being articulated at the community level in compassionate and orthodox forms of medical care, and in tight-knit and positive social relations.

\section{Bibliography}

\section{Primary Sources}

Chao Yuanfang 巢元方 610, Zhubing yuanhou lun jiaozhu 諸病源候 論校注 (Treatise on the Aetiology and Symptoms of Diseases). Modern edn: Ding Guangdi 丁光迪 et al. (eds), Beijing: Renmin weisheng chubanshe, 1991.

Cheng Jiong 程迥 (jinshi 1163) 1176, Yijing zhengben shu 醫經正本書 (Book on the Correct Foundations of the Medical Canon), in Wang Yunwu 王雲五 (ed.) 1939, Congshu jicheng chubian 叢書集成初 編 (Compendium of Collectanea, 1st edn), vol. 1,383, Shanghai:

59 I do not know of any extant eulogies for merchants, and speculate here that such a eulogy would, like literati eulogies, emphasise career and other public accomplishments.
Shangwu yinshuguan.

Li Fang 李昉 et al. (eds) [1961] 1981, Taiping guangji (Extensive Records of the Taiping Era), Beijing: Zhonghua shuju.

Li Tao 李壽 (1115-84) (ed.) Xu zizhi tongjian changbian 續資治通鑑 長編 (Extended Continuation of Comprehensive Mirror to Aid in Government).Modern edn:Shanghai:Shanghai guji chubanshe, 1986.

Lunyuyizhu 論語譯注 (Translation and Commentaries of the Analects). Modern edn: Yang Bojun 楊伯峻 (ed., comm.), Beijing: Zhonghua shuju, 1980 .

Meng Yuanlao 孟元老 (fl.1126-47), Dongjing menghua. Modern edn: Taibei: Dali chubanshe, 1980.

Hong Mai 洪邁 (1123-1202), Yijianzhi 夷堅志 (Records of the Listener). Modern edn: Beijing: Zhonghua shuju, 1981.

Okanishi Tameto 岡西為人 1969 (reprint), Sō izen iki kō 宋以前醫 籍考 (Studies of Medical Books of the Song and Earlier), Taipei: Guting shuwu.

Peng Dingqiu 彭定求 (1645-1719) et al. (comp.) Quan Tang shi 全唐诗 (Complete Tang Poetry). Reprint: Beijing: Zhonghua shuju, 196o.

Porter, D. (ed.) 2012, Comparative Early Modernities, 1100-1800, New York: Palgrave Macmillan.

Quan Tang shi 全唐詩, Peng Dingqiu 彭定求 et al. (eds), Beijing: Zhonghua shuju, 196o.

Sun Simiao 孫思邀 (d. 682?), Qianjin yifang 千金翼方. Modern edn: Taibei: Ziyou chubanshe, 1959.

Wang Huaiyin 王懷隱, et al. 992, Taiping shenghuifang 太平聖惠方. Modern reprint: Beijing: Renmin weisheng chubanshe, [1958] 1982.

Xu Song 徐宋 (1781-1848) (comp.), Song huiyao jigao 宋會要輯稿 (Compilation of Official Documents of the Song). Modern edn: Beijing: Guoli Beiping guoshuguan, 1936.

Zhao Ji 趙佶 (Song Huizong 宋徽宗) $1118 \mathrm{CE}$, Shengjizonglu 聖濟總錄 (Comprehensive Record of Sagely Beneficence), vol. 1. Modern edn: Beijing: Renmin weisheng chubanshe, [1962] 1992.

\section{Secondary Sources}

Baldrian-Hussein, F. 1986, 'Lü Tung-pin in Northern Sung literature', Cahiers d'Extrême-Asie 2, 133-69.

Bol, P.K. 2006, 'Emperors can claim antiquity too: emperorship and autocracy under the new policies', in Ebrey and Bickford (eds), 173-205.

Chaffee, J. 2006, 'Huizong, Cai Jing, and the politics of reform', in Ebrey and Bickford (eds), 31-77.

Cheng Minsheng 程民生 2008, Songdai wujia yanjiu 宋代物價研 究 (Commodity Prices in the Song), Beijing: Renmin chubanshe.

Cheng, Wen-Chien 2005, 'Drunken village elder or scholar-recluse? The ox-rider and its meanings in Song paintings of "Returning home drunk"', Artibus Asiae 65.2, 309-57.

2011, 'Antiquity and rusticity: images of the ordinary in the "Farmers' Wedding" painting', Journal of Song-Yuan Studies 41, 67-106.

Cherniack, S. 1994, 'Book culture and textual transmission in Sung China', Harvard Journal of Asiatic Studies 54.1 (June), 5-125.

Chia L. and H. de Weerdt (eds) 2011, Knowledge and Text Production in an Age of Print: China, 9oo-140o, Leiden: Brill.

De Pee, C. 2010, 'Purchase on power: imperial space and commercial space in Song-dynasty Kaifeng, 960-1127', Journal of the Economic and Social History of the Orient $53,149-84$.

Ebrey, P.B. 2014, Emperor Huizong, Cambridge, MA: Harvard University Press.

Ebrey, P.B. and M. Bickford (eds) 2006, Emperor Huizong and Late Northern Song China: The Politics of Culture and the Culture of Politics, Cambridge, MA: Harvard University Asia Center.

Deng Qiaobin 鄧喬涁 2005, Songdai huihua yanjiu 宋代繪畫研究 (Song Dynasty Painting), Kaifeng: Henan daxue chubanshe. 
Goldschmidt, A.M. 2006, 'Huizong's impact on medicine and on public health', in Ebrey and Bickford (eds), 275-323.

2009, The Evolution of Chinese Medicine: Song Dynasty, 960-1200, London: Routledge.

Gong Yanming 竟延明 1997, Songdai guanzhi cidian 宋代官職辭典 (Dictionary of The Civil Service System in the Song Period), Beijing: Zhonghua shuju.

Guoli gugong bowuyuan 國立故宮博物院 2010, Wenyi shaoxing: Nan Songyishuyuwenhua 文藝紹興: 南宋藝術與文化 (Dynastic Renaissance: Art and Culture of the Southern Song), Taibei: Guoli gugong bowuyuan.

Hammers, R.L. 2011, Pictures of Tilling and Weaving: Art, Labor, and Technology in Song and Yuan China, Hong Kong: Hong Kong University Press.

Hartman, C. 1995, 'Stomping songs: word and image', Chinese Literature: Essays, Articles, Reviews, 17 (December), 1-49.

Hinrichs, TJ 2003, The Medical Transforming of Governance and Southern Customs in Song Dynasty China (96o-1279 CE), PHD diss., Harvard University.

2011, 'Governance through medical texts and the role of print', in Chia and de Weerdt (eds), 217-38.

2015, 'The catchy epidemic: theorization and its limits in Han to Song period medicine', East Asian Science, Technology, and Medicine 41, 19-62.

Hinrichs, TJ and L. Barnes (eds) 2013, Chinese Medicine and Healing: An Illustrated History, Cambridge: Belknap Press of Harvard University Press.

Hinrichs, TJ and Jeehee Hong 2013, 'New perspectives on technical knowledge, funerary rites, and social status in the Northern Song: evidence from a recently discovered tomb' (conference presentation), Templeton International Conference on 'Science and Religion in East Asia, Seoul National University (1 December).

Hong, Jeehee and TJ Hinrichs 2015, 'Unwritten life (and death) of a "pharmacist" in Song China: decoding Hancheng tomb murals', Cahiers d'Extrême-Asie 24, 231-68.

Kang Baocheng 康保成 and Sun Bingjun 孙秉君 2009, 'Shaanxi
Hancheng Songmu bihua kaoshi' 陕西韩城宋墓壁画考释 (Analysis of the Song tomb murals at Hancheng, Shaanxi province), Wenyi yanjiu $11,79-88$.

Lewis, M.E. 2006, The Construction of Space in Early China, Albany: State University Press of New York.

Murray, J.K. 1997, 'Water under a bridge: further thoughts on the "Qingming" scroll', Journal of Song-Yuan Studies 27, 102-5.

Ni Zaiqin 倪再沈 1991, Li Tangji qi shanshui hua zhiyanjiu' 李唐及其 山水畫之研究 (Studies of Li Tang and his Landscape Painting), Taipei: Wenshizhe chubanshe.

Powers, M. 2012, 'Visualizing the state in Early Modern England and China', in Porter (ed.), 217-44.

Shiba Yoshinobu 斯波義信 1970, Commerce and Society in Sung China, tr. M. Elvin, Ann Arbor: University of Michigan.

Sivin, N. 1995, 'State, cosmos, and the body in the last three centuries BC', Harvard Journal of Asiatic Studies 55.1 (June), 5-37.

Stanley-Baker, M. 2013, 'Daoists and doctors: the role of medicine in Six Dynasties Shangqing Daoism', PHD diss., University College London.

Tsao Hsingyuan 2003, 'Unraveling the mystery of the handscroll "Qingming shanghe tu"', Journal of Sung-Yuan Studies 33, 166-7.

Unschuld, P.U. 1985, Medicine in China: A History of Ideas, Berkeley: University of California Press.

2000, Medicine in China: Historical Artifacts and Images, Munich: Prestel.

Wong Cheung Wai 王章偉 2005, Zaiguojia yu shehuizhijian: Songdai wuxi xinyang yanjiu 在國家與社會之間-宋代巫項信仰研究 (Between State and Society: Shamanistic Beliefs in the Song), Hong Kong: Zhonghua shuju.

Wu Hung 2010, The Art of the Yellow Springs: Understanding Chinese Tombs, Honolulu: University of Hawai'i Press.

Xu Guangji 徐光冀 (ed.) 2012, Zhongguo chutu bihua quanji 中國出 土壁畫全集 (Complete Collection of Murals Excavated in China) vol. 2, Beijing: Kexue chubanshe.

Zhou Baozhu 周寶珠 1997, 'Qingming shanghe tu' yu Qingming shanghe xue 〈清明上河圖〉與清明上河學 (The Qingming Scroll and Qingming Scroll Scholarship), Kaifeng: Henan daxue chubanshe. 